\title{
THE EVOLUTION OF A LEGAL SYSTEM
}

Sir Geoffrey Palmer

Notes for a dialogue between Sir Ivor Richardson and the Rt Hon Sir Geoffrey Palmer held at the Australasian Law Teachers' Association Conference at Victoria University of Wellington, 6 July 1999.

This session has been billed as a dialogue between Sir Ivor and me. While we have had some preliminary discussions and some interchange of views, we were not quite sure how we were going to enter into a dialogue.

As a humble solicitor, I feel very reserved about entering into dialogue with the President of the Court of Appeal.

I have noted that law practitioners are particularly prone not to criticise judges - a characteristic not shared by academic lawyers.

But, in any event, there is nothing in what Sir Ivor has said that I would wish to criticise; his remarks are characteristically careful, measured, balanced and helpful.

Sir Ivor has dwelt to quite a large extent on the role of the courts. I want to switch the emphasis.

As an academic lawyer, I always thought that law students, law academics and the Law Review spent too much time analysing judgments and too little dealing with statutes and regulations. Lawyers are more proficient it seems to me in analysing judicial activity than they are legislative activity. My experience in practice has reinforced that belief.

I am convinced that this tendency needs to be changed and, while it has changed to some extent in recent years, there is a long way to go.

Some years ago I wrote an article in the Victoria University of Wellington Law Review

* Honorary Lecturer, Victoria University of Wellington; Partner, Chen \& Palmer, Barristers \& Solicitors, Public Law Specialists. 
called "The New Zealand Legislative Machine". ${ }^{1}$ I was, when I wrote it, Chairman of the Cabinet Legislation Committee, Deputy Prime Minister, Attorney-General and Minister of Justice. I would like to rehearse with you the first two paragraphs of that Law Review article which was published in 1987:

There are two famous quotations about legislation with which I would like to start. One is attributed to Lord Thring who in 1869 became the first parliamentary counsel ever appointed in England. It reads "Bills are made to pass as razors are made to sell". It is a somewhat puzzling quotation the original of which has been traced by Sir George Engle (himself currently first parliamentary counsel in the United Kingdom) to a popular poem of the day. ${ }^{2}$ The saying has lasted because it encapsulates a truth: the first requirement of a bill is to pass through Parliament, and during its passage constraints and pressures are applied which have a powerful influence on its final shape. The second quotation comes from Woodrow Wilson, "[o]nce begin the dance of legislation, and you must struggle through its mazes as best you can to its breathless end - if any end there be". ${ }^{3}$ It makes a similar point, albeit more pessimistically. This latter quotation inspired the title of a brilliant American book about the progress of one bill through the United States Congress. ${ }^{4}$

The dance of legislation is indeed intricate. Each bill is a different dance and each dance has many different steps. The dance requires perseverance, stamina and a large degree of esoteric knowledge. The purpose of the process is not to provide an obstacle course for good ideas but to provide checks and balances and quality controls on the content of new legislation. In this essay I want to look at the mechanics of the New Zealand legislative process and briefly consider what improvements could be made. In the single chamber Parliament of New

1 Sir Geoffrey Palmer "The New Zealand Legislative Machine" (1987) 17 VUWLR 285.

2 G Engle "'Bills are made to pass as razors are made to sell': practical constraints in the preparation of legislation" [1983] Statute Law Review 7.

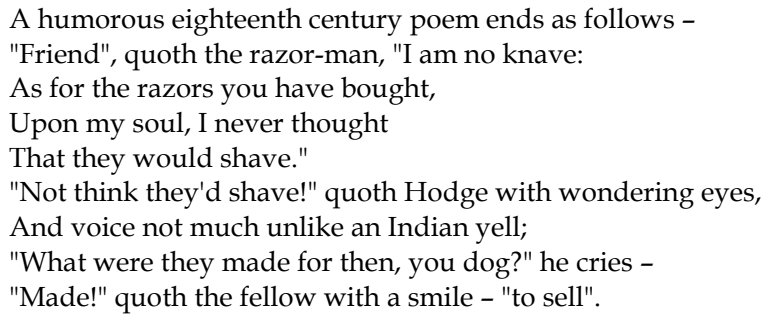

3 W Wilson Congressional Government A Study in American Politics (15 ed, Houghton, Mifflin, Boston, 1973) 397.

4 E Redman The Dance of Legislation (Simon \& Schuster, New York, 1973). An interesting British book is H S Kent In on the Act (MacMillan, London, 1979). 
Zealand, making law is no doubt simpler than in other countries. Nonetheless, it is extraordinarily complicated and consists of a complex interaction of each stage between a variety of institutions and personalities.

The judgment expressed in the latter part of that passage remains, in my opinion, an accurate account of the way the system was then. The way the system is now is fundamentally different. It is evolving away from the position that the executive government controls the shape of Parliament's legislative output.

The developments of the New Zealand legislative process under MMP have been substantial. I am not at all sure that those who do not watch the process closely have caught up with how radical the changes have been. We are now approaching a situation where the Executive proposes and Parliament disposes.

For those people who are familiar with and have worked in jurisdictions with two Houses of Parliament, the process of negotiated legislation that is emerging in New Zealand would not be unfamiliar. But in the context of New Zealand, used to a unicameral legislature elected under First Past the Post, the changes have been dramatic.

Furthermore, the political situation in the first MMP Parliament has been characterised by a number of features that have made it difficult for the Parliament to settle down. These are:

- An unprecedented number of new members unfamiliar with the procedures;

- A record number of parties - six elected and now expanded to nine;

- Some extraordinarily bitter personal interchanges in the House resulting from the way the Coalition was set up in 1996 and also from the break-up of the Coalition; and

- A total revision of the Standing Orders in preparation for MMP which were, in many instances, themselves experimental.

New Zealand, in the period since the general election in 1996, has experienced Majority Coalition Government and Minority Government. ${ }^{5}$ The legislative features of each are rather different.

It was, for example, possible to accomplish under the Majority Coalition Government reforms as radical as those contained in the Electricity Industry Reform Act 1998. This statute received the Royal Assent on 8 July 1998 and the Coalition broke up in August.

5 Ed note: This paper was delivered before the 1999 general election. 
Even then, the Prime Minister declared the matter to be a question of confidence. And the issue of making legislative issues ones of confidence no doubt occurs in Minority Government, although it is impossible to be precise as to how much, since the negotiations take place behind closed doors.

The outward signs of government still behave as if the Government is in charge of the legislative programme. Underneath it is a different story, although the Standing Orders still provide that there is a fundamental distinction between Government Bills and Members' Bills, as well as between Local Bills and Private Bills.

In order to understand what has occurred in the legislative process, it is probably necessary to examine what effects MMP has had on the conduct of the Legislature. MMP and Parliament was the subject of a lengthy report in 1995 - The Report of the Standing Orders Committee on the Review of the Standing Orders. ${ }^{6}$ That Review was carried out in order to anticipate what the demands of an MMP Parliament may be. To quite a large degree those changes appear to have worked quite well, but more changes will be needed as a result of the experience of the past three years. The Standing Orders Committee is currently sitting.

Chapter V of the 1995 Report dealt with legislative matters. It forbade one of the methods that Governments had used in the last few years to fast-track legislation - the use of Omnibus Bills: the Law Reform (Miscellaneous Provisions) Bill that constituted a legislative train to which many carriages could be added. The Standing Orders on Omnibus Bills are worthy of attention:

\section{Types of omnibus bills that may be introduced}

(1) The following types of bills may be introduced although they are omnibus in nature-

(a) Finance bills or confirmation bills that validate or authorise action otherwise illegal or validate and confirm regulations:

(b) Local Legislation bills that contain provisions affecting particular localities that would otherwise have been introduced as local bills:

(c) Maori Purposes bills that-

(i) amend one or more Acts relating to Maori affairs, or

(ii) deal with authorisations, transfers and validations in respect of Maori land and property:

(d) Reserves and Other Lands Disposal bills that-

6 The Report of the Standing Orders Committee on the Review of the Standing Orders [1995] AJHR I 18A. 
(i) deal only with authorisations, transfers and validations of matters relating to Crown land, reserves and other land held for public or private purposes, or

(ii) amend a previous Reserves and Other Lands Disposal Bill:

(e) Statutes Amendment bills that consist entirely of amendments to Acts.

(2) Matter more appropriate for inclusion in a Local Legislation Bill, a Maori Purposes Bill, or a Reserves and Other Lands Disposal Bill is to be included in one or those types of bills rather than a Finance Bill.

259 Law reform or other omnibus bills

A law reform or other omnibus bill to amend more than one Act may be introduced if-

(a) the Acts to be amended deal with an interrelated topic that can be regarded as implementing a single broad policy, or

(b) the amendments to be effected to each Act are of a similar nature in each case, or

(c) the Business Committee has agreed to the bill's introduction as a law reform or omnibus bill. *

These provisions have been steadfastly enforced.

The Standing Orders Committee also thought that procedures concerning the New Zealand Bill of Rights Act 1990 should be tightened up. The Committee thought that the then existing Standing Orders were not sufficiently specific about how the procedure was to be followed. It decided that the best way in which the Attorney-General's obligation to report to the House could be fulfilled was by presentation of a report that is published by order of the House as a Parliamentary Paper.

The legislative process was also changed in a rather fundamental fashion by the same Standing Orders Committee Report recommendations which were adopted by the House. The situation is now:

\section{First reading}

No debate 
Second reading

Main debate in House of Representatives

\section{Select Committee}

Study and public submission

Report presented to Clerk of the House

Report back to House

Debate in the House on

the Select Committee's report

\section{Committee of the Whole House}

Clause by clause debate

Third reading

Final debate 


\section{Royal Assent}

Bill is passed - becomes an act

The Committee of the Whole House stage can be removed altogether by a decision of the Business Committee and, indeed, the role of the Business Committee under the new Standing Orders promised to be a very significant one, but I am not at all sure that it has worked out in practice the way its framers intended. However, it has been a useful forum for all the political groups to be briefed as to the Government's legislative plans and react to them - a sort of Whips' Committee.

The major change, of ensuring that there should be no debate of Bills on introduction, was designed to allow Members of Parliament to read them before they had to debate them. It is not possible to quarrel with that. I have had some experience of debating Bills that have been in my hands for ten minutes or half an hour; it is not a happy experience.

The changes that were made at that time also included a very beneficial one; the Select Committee was to provide a report in prose printed at the front of the Bill as reported back describing what the Committee did and why. These are particularly helpful reports in terms of those whose professional interests require them to research the legislative history of statutes, and that must be counted as a very successful and helpful reform.

The question about the new procedure is that it has turned out in practice rather differently than its designers anticipated. On many occasions there is no commitment one way or the other in the second reading debate. The smaller political parties in particular will support matters going to a Select Committee for examination, but they will not commit themselves for or against a measure until they have had the opportunity of seeing the Select Committee's consideration of it as the result of public submissions.

There is a case for turning the existing second reading debate into something like the old introductory debate where members asked questions. The second reading debate could then be dealt with instead of the report back to the House debate as at present, but in conjunction with the report back. The Standing Orders Committee is sitting and no doubt will, before this Parliament ends, deliver its recommendations concerning these matters.

Furthermore, limited time debates which were another big change made by the 1995 Select Committee have cut down time-wasting debate on legislation. The time is limited for all stages except the Committee of the Whole House, and that stage can be eliminated. For example, it was done twice last week by leave. 
It was anticipated that there would be an increase in Members' Bills in 1995 - indeed there had been since early in the life of that Parliament. They are a growth industry. The Committee devised a rationing process which is now governed by the Standing Orders with a periodic ballot that members look forward to very considerably. One member has won the ballot three times! Others not at all. There are usually 30 or 40 Bills in the ballot. It is conducted by the Clerk of the House.

It was anticipated at the time that further drafting resources would be required and, while there has been additional legally qualified staff made available to the Clerk of the House, it appears that the demand for the services outstrip the capacity to supply. The Standing Orders Committee said:

We are of the view that Parliament must examine whether it should have its own drafting and legal advisory service which would be able to give independent and contestable advice.

So far that view has not been acted on fully. Statistics for Members' Bills for the current Parliamentary session are instructive:

Eighty-seven Members' Bills have been introduced in the current session.

Thirty-four Bills have been negatived at the second reading stage.

Seventeen Bills have been negatived following Select Committee stage.

Twenty-eight Bills are still active.

Three Bills were discharged.

Two Bills were referred back to their Select Committee.

Three Bills were passed:

- Education (Tertiary Students Association Voluntary Membership) Amendment 1998 (Steel);

- $\quad$ Misuse of Drugs Amendment 1997 (John Carter);

- $\quad$ Trade in Endangered Species Amendment 1997 (Roy).

These figures do not take into account the occasions when the Government has introduced a Bill of its own and adopts for itself in whole or in part the policy adopted in a Members' Bill. There have been some notable examples of this - a Parental Leave Bill promoted by an Opposition member led to the Taxation (Parental Tax Credit) Act 1999.

Perhaps the most notable feature of MMP in the short time that it has been a feature of the New Zealand political landscape has been the distinction as now delineated between Parliament on the one hand and the Executive Government on the other. It has been a 
notable feature of MMP, particularly in its later phases with a minority Government, that the Government is not able to secure its own policy preferences through Select Committees and even on the floor of the House itself. The incentives that are on politicians to make policy bids are very considerable in the existing system. The incentives on them to differentiate their political brand from those of the other competing political parties are also substantial. Those pressures need to be understood and they need to be allowed for in any policy design.

There are a number of key features that can be isolated and analysed concerning the performance of MMP in the New Zealand Parliament already. It is necessary to take these on board and make allowances for them in the design of the legislative process.

The first and most obvious has already been adverted to. Parliament and Opposition parties determine the continued existence of minority Government. While we have not had the instability that some of the commentators thought MMP may bring upon us, there is no doubt that the continuing existence of the present Government depends on Parliamentary support from outside its own ranks. This means that the Parliament and the Executive Government inter-relate with each other in ways that are fundamentally different from the way that they did under the First Past the Post system.

Where there is a coalition, there is less pressure on Cabinet Ministers to agree publicly with coalition Cabinet decisions. That has already been demonstrated, and it has been demonstrated in the retirement income debate on which New Zealand had a referendum in 1997. Various Ministers took different positions in that debate in the run up to the referendum.

The role of the Prime Minister and senior officials in co-ordinating Ministers and officials is more difficult under MMP. That appears to be true whether it is a coalition or minority government. It is simply different things that are being co-ordinated in each case but they are co-ordination tasks that are equally difficult.

Select Committees are much more important to the passage of legislation and the scrutiny of Government than they were under First Past the Post. Given that proportionality is the principle upon which Select Committee memberships are made in the House, lack of a Government majority means that the Government does not have a majority on many Select Committees. It has been a notable feature of the last year that Select Committees have flexed their muscles to a greater and greater extent. This can mean that legislation will be fundamentally altered or even not proceeded with, whatever the views of the Government.

The New Zealand system of scrutinising Government Bills is one of the most developed in the Commonwealth. That is because, in my view, we do not have a Second Chamber. In many ways, Select Committees have operated as one. They hear public 
submissions on all Bills except those that are passed under urgency. The Bills are frequently altered dramatically as a result of the submissions. This goes back quite a long time in our history and certainly pre-dates MMP. But MMP has allowed the situation to develop very considerably. For example, in the present House of Representatives, of the 17 standing Select Committees, the Government lacks a majority on all of them in a strict sense. But if informal Parliamentary support is taken into account, the situation is not so serious. But, even on this analysis, the Government controls only about half of the Select Committees. It is hard these days to say what is an Opposition MP.

A corollary of the above principle is that legislation that is not supported by a minority government, and sometimes a coalition government, may be passed. This has happened, and it is likely to happen further.

Parliament and Opposition parties effectively now determine whether particular minority Government policies will be implemented through legislation. Their activities in the Parliament also define issues and may produce Ministerial resignations to a greater extent than they did before.

Public servants tend to face more direct pressure from Opposition politicians under MMP than they did before. Constitutionally inappropriate questioning takes place at Select Committees and it is really impossible for Ministers to protect officials or their own appointees. The results have been apparent, particularly in Crown entities, where quite a number of Government appointees have resigned or been forced to resign.

It can be argued that more meaningful public debate over Government policy has resulted from MMP than was previously the case. There has been increased inter-Party negotiation and perhaps more public debate on the virtues of policies before they are adopted than there used to be. It is further evident that, to some extent, the MMP process has slowed down the process of legislating. A corollary may be that it has increased the levels of public consultation that go into Government policy. Consensus is much more important than it used to be.

The fundamental constitutional point is that the Executive is less dominant than it was and certainly less able to control the legislative programme than it used to be. It may be that it is also prone to be required to spend money in areas where that would not have occurred before, but the record on this is less clear.

The implications of the MMP configuration of Parliament for legislation are obvious. It is necessary to design the policy carefully and with wide consultation long before it is introduced. It will be necessary to get buy-in from a majority of MPs. Hence the phenomenon of negotiated legislation. 


\section{CONCLUSION}

The legislative process of the New Zealand Government has become a great deal more intricate and complex as a result of MMP. This places considerable pressures on a number of people. They are:

- Ministers;

- MPs;

- Parliamentary Counsel;

- Select Committees and their staff;

- Public servants.

The techniques of political management in relation to legislation in the new configuration of Parliament have not advanced much, but they have advanced to some extent. It is now readily accepted on all sides that important negotiations must take place on the policy contained in legislation. The Government attempts to avoid introducing measures for which it does not have the support, and it sometimes has to engage in lengthy and difficult negotiations in order to secure that support in advance.

Furthermore, the capacity of legislation to be unhorsed as it travels through the legislature procedures is enhanced. Select Committee submissions and concerted efforts to persuade particular political parties and groupings in the Parliament that a measure is bad can sometimes yield success.

The added complication where the Government's own supporters will not vote for a measure also brings considerable difficulties.

There are situations where this places public servants in a very exposed position. If they are in front of a Select Committee advising on a measure, they must represent the Minister's interests and no-one else's. They are public servants. This is the basic constitutional principle. How therefore does the Select Committee get adequate advice on what it may want to do if what it wants to do is not what the Minister wants to do? There are emerging and nascent practices in this regard of great interest, and it will be fascinating to see how they develop.

Furthermore, there is the question of drafting standards. The prospect of Bills reaching the statute book other than Government-drafted Bills or Government-drafted amendments is substantial. The Parliamentary Counsel Office has had its resources increased, but unless some arrangements are made to provide the proper professional servicing of these legislative activities, the coherence of the statute book will deteriorate. 
Purists might argue that the financial veto procedure could be used to defeat Bills and Members' Bills that involve expenditure, but such an analysis overlooks entirely the dynamics of the minority government in an MMP system. The Government has to be extraordinarily cautious before it uses that power and, indeed, the short experience we have had so far would indicate they are very cautious about it.

All of this suggests that the creation of sets of legislative standards and practices is an urgent priority in New Zealand. The Legislation Advisory Committee, despite some valiant attempts, has not managed to exert much influence over the system. It is an influence that is urgently required. My solution to this problem is offered in another paper - the need for a reformed Government legal service - but I will not burden you with that again here. 
